\title{
Who Supports the US-led Global Order? An Empirical Analysis Using Survey Data
}

\author{
Alec Chung1
}

\begin{abstract}
Regarding the future of global leadership, there are four possible scenarios in a broad sense - the world led by 1) the US, 2) China, 3) both the US and China (G-2), and 4) neither the US nor China (G-0). Analyzing survey data, I examined which of the four scenarios individuals in democracies think would be better for the world in the future. The empirical results show that individuals who have a positive perception of the US and those who perceived China's power and influence negatively were more likely to prefer the global order led by the US than China. Further, individuals who think they live in a state where democratic values such as transparency, fairness, and freedom are respected were also more likely to support the US than China as the global leader. The results suggest that those in favor of democratic values such as transparency, fairness, and freedom do not want to see a world led by China, which is regarded an authoritarian state. Finally, individuals who have a positive attitude toward trade were more likely to prefer a global order led by the US compared to one led by the G-2. However, attitudes toward trade did not affect one's preference for a US or China-led global order. Overall, positive attitudes toward the US, negative views of China, and support for democratic values increased the likelihood that individuals would support a US-led global order.
\end{abstract}

Key Words: Global leadership, the United States, China, public opinion, empirical analysis

* Alec Chung received his Ph.D. from the Department of Political science at the University of Florida. He is currently working as a research fellow at the Jeju Peace Institute (JPI). His research interests include peace and conflict in East Asia, political economy of East Asia, China-Japan-ROK relations, and the connection between public opinion and foreign policy in East Asian countries. (E-mail: scchung@jpi.or.kr) 


\section{INTRODUCTION}

The end of the Cold War in the early 1990s opened the gates to a unipolar world led by the US. As a result, the US played the role of a hegemon, acting as a world leader throughout the 1990s. However, US hegemony started to decline in the 2000s as the US got caught in quagmires such as wars in Afghanistan and Iran (which started in 2001 and 2003, respectively) and was hard-hit by the 2008 global financial crisis. Meanwhile, China's economy continued to grow rapidly by recording double-digit growth almost every year throughout the 1990s and 2000s, narrowing the economic gap with the US. Thus, some say we are already living in an era of G-2 led by the US and China together. Under current circumstances, this article's main goal is to investigate, using survey data and statistical analysis, whether people think the US should lead the world or China should become the new global leader. Or if the two states should lead the world together or none of them should.

Although countless pieces of literature discuss whether US hegemony is declining and whether China is trying to to become a new global leader, few scholars have studied what individuals all over the world think about global leadership. The reason why we should pay attention to public opinion is because individuals can wield influence over the foreign policy decisions of their governments. Especially in democracies, individuals are also voters at the same time, having the power to pressure their governments to adopt policies that serve their interests (Page and Shapiro 1983). For this reason, I have limited the scope of this study to democracies where individuals' opinions can be one of the decisive sources of government decisions.

To study the research question, we first need to find out what portion of the global population supports 1) a US-led global order, 2) seeks a China-led new order, 3) thinks the G-2 should lead the world together, and 4) believes neither should assume leadership. Second, we also need to investigate the factors that shape individuals' attitudes toward global leadership. Those factors could be related to individuals' views of a particular state or a global issue (individual-level variables) in a broad sense. Otherwise, political and economic relations between the respondents' home state and the US (or China) can also shape their views toward the two great powers (state-level variables).

Analyzing the 2018 Pew Research Center (PRC) Global Attitudes \& Trends Spring 2018 survey dataset, I investigated which of the four scenarios individuals in democracies think would be better for the world - a world led by 1) the US, 2) China, 3) both the US and China (G-2), and 4) neither the US nor China (G-0). The empirical results show that individuals who have a positive perception of the US 
and a negative attitude toward China were more likely to think the US should continue to lead the world. Secondly, individuals who believe their home state respects democratic values were more likely to choose the US as a state that should lead the world in the future. The result suggests that those who think they live in a free and fair society where their and rights are being protected do not want to see a world led by China, which is regarded an authoritarian state. Finally, individuals who have a positive attitude toward trade were more likely to prefera global order led by the US compared to one led by the G-2. However, attitudes toward trade did not affect whether one thinks US or Chinese leadership would be better for the world. Overall, positive attitudes toward the US, positive perception of one's own country's state of democracy, and negative attitudes toward China increased the likelihood that individuals would support a US-led, rather than a China-led, global order.

This paper will proceed as follows. In the next three sections, I will review the literature and introduce the four potential scenarios of future global leadership, potential sources of positive and negative sentiments toward the US and China, and the connection between public opinion and foreign policy. Then, based on the literature and scenarios, I will suggest hypotheses that need to be tested to find the factors that affect individuals' choice of future global leadership. Next, after introducing the data, multilevel multinomial logistic regression models will be used to analyze the data empirically. Finally, I conclude by discussing the main findings obtained through the empirical analysis and their implications.

\section{POSSIBLE SCENARIOS OF GLOBAL LEADERSHIP}

Since the end of the Cold War, the US has acted as the global leader because it was the sole hegemon capable of doing so. As of 2020, the US still has the largest economy in the world, which is close to US\$ 21 trillion (accounting for approximately a quarter of the world's Gross Domestic Product). Also, the US maintains the largest military budget in the world, which is larger than the total of all the other states' budgets combined. Besides its superior material capabilities, the US also wields strong influence worldwide through its soft power based on liberal values such as democracy, free market, and human rights (Nye 2016). Furthermore, the US has acted as the leader of the world by making the most extensive material contributions to various multilateral institutions such as the United Nations (UN) and its Specialized Agencies, World Bank, International Monetary Fund (IMF), World Trade Organization (WTO), North Atlantic Treaty Organization (NATO), and others. The US has also intervened 
militarily in places such as the Balkans in the 1990s and the Middle East (Afghanistan, Iraq, Libya, and Syria) throughout the 2000s and 2010s. With respect to US intervention in the Middle East especially, the US initiated the global war on terror and acted as global policeman, although it raised controversy even among its allies.

However, since the beginning of the $21^{\text {st }}$ century, several events have damaged the US's image as a reliable leader. Those events include the global "war on terror" campaign, which the US launched after the 9/11 attacks in 2001 and further led to the invasion of Afghanistan in October 2001 and Iraq in March 2003. Next, the US was the epicenter of the 2008 global financial crisis. Especially regarding the "war on terror," debates continue on whether it has made the world a safer place from terrorism than before (Chellaney 2019).

Other than damaging its image and reputation as the world's leading military and economic power, such events have also caused financial damage to the US. With the 2008 global financial crisis, excessive spending on the global war on terror has significantly increased US government debt, eroding US economic hegemony.

While US economic hegemony showed signs of decline, there have also been signs that the US is showing intentions to relinquish its status as the global leader. For decades, the US regarded the existing multilateral order as efforts by other states to "tie Gulliver down," restricting its actions through institutional frameworks (Ikenberry 2003). For instance, under the leadership of the Trump Administration, the US showed moves of retreating from the multilateral international order such as withdrawing from the Trans-Pacific Partnership (TPP) trade deal and the Paris Agreement on climate change mitigation (in 2017), paralyzing the WTO by blocking the appointments at its appellate body (in 2019), and withdrawing from the World Health Organization (WHO) amid the global Coronavirus Disease-19 (COVID-19) crisis (in 2020).

On the other hand, unlike the US, China has been actively using foreign aid as a tool to increase its influence in developing countries, especially in Africa (Morgan 2019). China also increased its contribution to various international institutions such as the IMF, WTO, World Bank, and WHO while committing to cut greenhouse gas emissions. China has also launched the Belt and Road Initiative (BRI) in 2013, a project aiming to build infrastructure that connects East Asia and Europe. The Initiative reveals China's ambition to expand its political and economic influence within the Eurasian continent. China's leader Xi Jinping also expressed China's intention to lead the regional cooperative movement and multilateralism during the Asian Infrastructure Investment Bank (AIIB) annual conference meeting (Wu 2020), unlike the US which is reluctant to lead other 
states during the global COVID-19 crisis. In short, if US global leadership continues to retreat, other states might consider China as an alternative that could act as a new global leader.

Other than either the US or China leading the world alone, another possible scenario is both states leading the world together. It is already widely said that we live in a G-2 era led by the US and China. Such a scenario would be possible if the two great powers would view each other as not having hostile intentions and if the current international order would not be viewed as a zero-sum game. As the level of economic interdependence between the US and China increases, both states might perceive cooperation as beneficial for their national interests.

The last possible scenario would be a global order where neither the US nor China assumes leadership. Such an absence of global leadership is regarded as a likely situation in the future when the US is reluctant to lead while it is uncertain whether China has both the ability and will to replace US leadership (Beeson and Watson 2019). In this case, the world could fall into the "Kindleberger trap." According to Kindleberger (2013), an absence of a hegemon (the UK no longer being able to act as a hegemon while the US lacked the will to act as one) was the main reason the Great Depression worsened in the 1930s. Hegemonic stability theories argue that the world needs a hegemon with both the ability and will to maintain an open and stable international order (Gilpin 2008; Kindleberger 2013). Thus, such a "G-0" world could be fraught with conflict between states with no hegemon to mediate.

On the other hand, there is little reason to be pessimistic about the G-0 world because states can still facilitate cooperation by constructing international regimes in the absence of a hegemon (Keohane 2005). In other words, because states learned the benefits of an open and stable international order when a hegemon existed, they can cooperate to maintain that very order even after the decline of a hegemon. Therefore, according to this logic, existing international institutions such as the UN, IMF, World Bank, WTO, and others will continue to play their roles as facilitators of cooperation (for instance, by reducing transaction costs and uncertainties) in a multipolar world. In short, the absence of a hegemon to lead the world does not mean that the existing international order will fall apart.

Overall, based on the literature reviewed in this section, there can be four possible scenarios for future global leadership - the world led by 1) the US, 2) China, 3) both, and 4) neither. 


\section{POTENTIAL SOURCES OF POSITIVE AND NEGATIVE SENTIMENTS TOWARD THE US AND CHINA}

Then, what are the potential factors that shape global public opinion on the US and China? Regarding individuals' perception of the US, Carlson and Nelson (2008) showed that individuals who enjoy a high standard of living are more likely to positively view the US. The authors also demonstrate that societies with large Muslim populations are more likely to express negative attitudes toward the US, probably due to a long history of US intervention in the Middle East. For instance, invading Afghanistan and Iraq increased anti-American sentiments not only in fellow Muslim states (Ahmad 2011) but also in Europe as well (Chiozza 2009).

On the other hand, among East Asians, the US is often regarded as a role model which their home state should emulate (Pan 2020). The US is viewed with admiration in East Asia because of its image as a hegemon that protects and spreads democracy while providing military assistance for their security. Besides, many East Asians have also seen the US for decades as one of the most advanced economies that their home states should imitate to modernize their economies. In short, pro-American sentiments stem from the US's image and reputation as an advocate of democracy, freedom, human rights, and the free-market system.

At the same time, anti-American sentiments also prevail worldwide. In a broad sense, the leading causes of the spread of anti-Americanism are fear and anxiety among the non-American public that the US will impose American culture, democratic values (that are regarded as incompatible with the home state's traditional way of life), and a free-market system (Berendse 2003; Jhee 2008; Plate 2013; Rubin and Rubin 2004).

Meanwhile, although one of the US foreign policy's leading goals is the spread of democracy across the world, the US often showed contradictory behavior. For instance, the US has often supported authoritarian leaders to protect its own national interest, raising anti-Americanism worldwide. For example, US support for Chun Doo-hwan's military regime after the Gwangju Uprising in 1980 (which is regarded as a symbolic event representing the democratization movement in South Korea) ignited anti-American sentiments in South Korea (Jhee 2008).

Moreover, while some individuals regard the presence of US military bases as a sign of robust military alliance with the US, others perceive it as a challenge to one's autonomy and sovereignty by the US. Besides, tension and conflict between local societies and US troops creates anti-American sentiments among the public (Yeo 2011), damaging state-level relationships.

Finally, trade relations with the US can lead to both positive and negative 
sentiments toward the US. While individuals who benefit from trade with the US may develop favorable attitudes toward it, anti-American sentiments might spread among those who lose from that trade relation (Lee 2007). Whether one wins or loses from trade with the US can also influence whether one supports their home state's alliance with the US.

Regarding their perception of China, its recent double-digit growth rate might have influenced individuals to choose China as a role model that their home state should emulate for economic development. Especially as the global public witnessed how China rebounded swiftly from the 2008-09 global financial crisis while the US economic growth stagnated for years after the event, some individuals might have become avid supporters of the Chinese authoritarian model that yielded a remarkable success in recent decades - advocating the Bejing Consensus model as an alternative to the Washington Consensus (Halper 2010).

However, the authoritarian nature of the Chinese government also breeds negative perceptions of China. For instance, the international community often condemned China for abusing the human rights of ethnic minorities (Kent 2013). Furthermore, China's rapid growth under the leadership of its authoritarian regime also stirs a sense of fear and anxiety among individuals. Thus, the rise of "China Threat" arguments produces and reproduces discourse that spreads negative sentiments toward China's rise (Christensen 1999, 2001; Krauthammer 1995; Krepinevich 2015; Mearsheimer 2010, 2014; Roy 1994, 1996, 2005).

Besides, while China has increased its economic influence in Africa and Latin America by providing foreign aid and increasing investments, China is also being accused of acting as "new imperialists or neoimperialists" (Liang 2007). Such an accusation arises as China promotes its authoritarian development model and conducts businesses with dictators that commit human rights violations. China is also blamed for causing deindustrialization and environmental degradation in Africa and Latin America, leading to a rise of anti-Chinese sentiments in these regions (Armony and Velásquez 2015).

Finally, similar to how bilateral trade potentially affected individuals' attitudes toward the US, the impact of trade with China could shape the public's perception of China. For example, Chung (2015) provided empirical evidence that winners of trade with China are more likely to perceive China favorably and not as a threat to their home state compared to those who are harmed.

In short, this section reviewed the potential sources of positive and negative sentiments toward the US and China. However, little research has been conducted so far on why we need to pay attention to the global public's opinion of the US and China. Specifically, why do we need to study which scenario the 
public wants to see in the future? Therefore, in the following section, I will elaborate on why public opinion can be a crucial force behind foreign policy, especially in democracies.

\section{The Nexus between Public Opinion and Foreign Policy}

In this study, I have limited the scope to democracies where individuals' opinions can be one of the decisive sources of government decisions. Thus, before moving on to the empirical analysis, the reason I decided to analyze public opinion using survey data should be clarified further.

Especially in democracies, where most individuals are also voters during the election, what the public thinks about other states can affect government leaders' foreign policy decisions. Since voters have the power to constrain policy makers in democracies (Page and Shapiro 1983), how a state acts can be affected by domestic preferences that reflect individuals' interests.

Furthermore, from the elected political leaders' view, their main goal is to win elections and retain their positions in office. Because leaders get their performance evaluated through elections, they have a strong incentive to pay attention and deliver what their constituents want (Gelpi and Grieco 2003). In other words, when making foreign policy decisions, leaders should be vigilant to "voter preferences" to achieve their goal - being (re)elected to office (Simmons 2003). As a result, political decisions can be made in democracies through a bottom-up approach (Moravcsik 1997).

The direction of the causality - whether it is the public opinion that shapes the government policies or vice versa - is still debatable. For instance, Sobel (2001) suggests that voters have less knowledge regarding foreign affairs than domestic issues. Also, Mearsheimer (1990) argues that public opinion is volatile and subject to elite manipulation, especially when it comes to national security issues. Nevertheless, several studies provide empirical evidence that supports the former logic - it is the public opinion that acts as a determinant of government foreign policies.

For example, Papayoanou provides empirical evidence based on pre-World War I Britain and Germany that state leaders adopt policies that reflect the "median preferences of vested interests," instead of adopting policies that the leaders think are necessary for the state (Papayoanou 1996, 47). Leaders make such decisions because they are aware that they might lose the next election by making decisions against voters' interests. Papayoanou's case shows that the public has the power to constrain the decision-makers, suggesting that public 
opinion can have significant influence on states' foreign policies.

McLean and Whang (2014) also showed that leaders take into account domestic actors' (such as voters and special interest groups) interests and opinions when making foreign policy decisions. Specifically, leaders are responsive to public opinion to gain voters' support and to, eventually, win the election that will allow them to keep their seats in office. As a result, when imposing sanctions on other target states, leaders design sanction policies in ways that will satisfy their constituents' interests. Similarly, Fordham (1998) demonstrates that the US government takes into account Americans' economic interests and security concerns when it makes decisions to intervene in foreign conflicts militarily.

This section discussed the connection between public opinion and foreign policy. Although more studies should be conducted to identify the direction of causality more clearly, several previous studies have shown that public opinion could wield influence when leaders make foreign policy decisions. Building on these findings, in the next section, I will conduct an empirical analysis of which scenario individuals favor and the factors that shape their views.

\section{Research Design and Hypotheses}

\section{Data}

To conduct the analysis, I utilized the 2018 Pew Research Center (PRC) Global Attitudes \& Trends Spring 2018 survey data. The responses of 30,109 individuals from 27 states are included in the original dataset. ${ }^{1}$ For the sake of the analysis, I removed 1,500 Americans from the sample because some of the questions I plan to employ as independent variables are not asked in the US. Also, theoretically, I assume that removing Americans from the analysis would reduce bias in the overall empirical results because they would be highly likely to select their own state as the best candidate to lead the world in the future. (The survey result also supports my assumption because $89.8 \%$ of Americans believed that it would be better for the world if the US would be the world's leading power in the future. The percentage was highest among the 27 states in the sample.) I also excluded 1,000 Russians from the sample because the main target of this study is individuals in democracies, as mentioned above. Among the 27 states included in the 2018 PRC survey data, only Russia was classified as a "Not Free" state,

1 The 27 states in the survey data are Argentina, Australia, Brazil, Canada, France, Germany, Greece, Hungary, India, Indonesia, Israel, Italy, Japan, Kenya, Mexico, Netherlands, Nigeria, Philippines, Poland, Russia, South Africa, South Korea, Spain, Sweden, Tunisia, UK, and the US. 
according to Freedom House (2017). All the other states, except Russia, were at least categorized as "Partly Free." Finally, India was removed from the sample because $37.48 \%$ of Indians selected "Don't know” or refused to answer when they were asked which of the four scenarios they prefer (the dependent variable). That is a significantly high percentage that could cause bias in the empirical results if left in the sample. To summarize, 25,088 respondents from 24 states were left in the dataset for analysis.

\section{DEPENDENT VARIABLE}

As mentioned above, this study plans to investigate which of the four possible scenarios the global public prefers. Thus, the 2018 PRC survey question asking which scenario would be better for the world (Q33) will be utilized as the dependent variable to measure which scenario individuals support.

Table 1. Summary of 2018 PRC survey Q33: Thinking about the future, if you had to choose, which of the following scenarios would be better for the world?

\begin{tabular}{ccccccc}
\hline & $\begin{array}{c}\text { The US is the world's } \\
\text { leading power (\%) }\end{array}$ & $\begin{array}{c}\text { China is the world's } \\
\text { leading power (\%) }\end{array}$ & $\begin{array}{c}\text { Both } \\
(\%)\end{array}$ & $\begin{array}{c}\text { Neither } \\
(\%)\end{array}$ & $\begin{array}{c}\text { Don't know/ } \\
\text { Refused (\%) }\end{array}$ & $\mathrm{n}$ \\
\hline Argentina & 33.40 & 36.50 & 2.60 & 18.00 & 9.50 & 1,000 \\
Australia & 70.84 & 13.40 & 0.70 & 11.75 & 3.31 & 1,149 \\
Brazil & 52.18 & 26.19 & 1.09 & 11.21 & 9.33 & 1,008 \\
Canada & 72.92 & 13.16 & 0.47 & 9.28 & 4.16 & 1,056 \\
France & 64.71 & 19.94 & 0.50 & 12.26 & 2.59 & 1,003 \\
Germany & 56.44 & 18.88 & 1.60 & 18.38 & 4.70 & 1,001 \\
Greece & 43.33 & 26.95 & 7.52 & 19.71 & 2.48 & 1,050 \\
Hungary & 46.61 & 9.58 & 11.58 & 21.46 & 10.78 & 1,002 \\
Indonesia & 41.99 & 23.32 & 9.29 & 15.57 & 9.83 & 1,098 \\
Israel & 56.80 & 17.10 & 13.80 & 8.60 & 3.70 & 1,000 \\
Italy & 39.79 & 17.83 & 17.16 & 19.85 & 5.37 & 1,043 \\
Japan & 80.61 & 7.58 & 0.49 & 7.38 & 3.94 & 1,016 \\
Kenya & 63.81 & 31.86 & 1.35 & 0.58 & 2.41 & 1,039 \\
Mexico & 46.38 & 39.13 & 2.23 & 5.13 & 7.14 & 897 \\
Netherlands & 72.37 & 14.31 & 0.60 & 9.05 & 3.68 & 1,006 \\
Nigeria & 55.08 & 37.12 & 1.28 & 0.69 & 5.83 & 1,013 \\
Philippines & 78.41 & 11.43 & 5.93 & 2.37 & 1.86 & 1,181 \\
Poland & 68.06 & 4.46 & 5.36 & 14.98 & 7.14 & 1,008 \\
South Africa & 44.90 & 39.64 & 7.63 & 4.25 & 3.58 & 1,481 \\
South Korea & 73.29 & 11.12 & 2.38 & 11.02 & 2.19 & 1,007
\end{tabular}




\begin{tabular}{ccccccc}
\hline & $\begin{array}{c}\text { The US is the world's } \\
\text { leading power (\%) }\end{array}$ & $\begin{array}{c}\text { China is the world's } \\
\text { leading power (\%) }\end{array}$ & $\begin{array}{c}\text { Both } \\
(\%)\end{array}$ & $\begin{array}{c}\text { Neither } \\
(\%)\end{array}$ & $\begin{array}{c}\text { Don't know/ } \\
\text { Refused (\%) }\end{array}$ & $\mathrm{n}$ \\
\hline Spain & 65.37 & 22.59 & 0.50 & 9.15 & 2.39 & 1,005 \\
Sweden & 78.16 & 11.32 & 1.01 & 5.06 & 4.45 & 989 \\
Tunisia & 25.41 & 64.31 & 0.58 & 7.86 & 1.84 & 1,031 \\
UK & 67.26 & 16.42 & 0.70 & 11.54 & 4.08 & 1,005 \\
Total & 58.16 & 22.43 & 4.11 & 10.51 & 4.78 & 25,088 \\
\hline
\end{tabular}

Table 1 shows that $58.16 \%$ of respondents in the survey data selected the US-led world as the most favorable future scenario, followed by the world led by China (22.43\%), neither the US nor China (10.51\%), and both the US and China (4.11\%). The percentages of respondents who prefer the US as the world's leading power were particularly high in Asia-Pacific region states such as Australia (70.84\%), Indonesia (41.99\%, which is higher than $23.32 \%$ who chose China), Japan (80.61\%), the Philippines (78.41\%), and South Korea (73.29\%). Such outcomes suggest that individuals in China's neighboring states believe that a US-led global order is better for their country, having the potential to influence their governments to adopt a more balancing stance toward China. Besides, individuals in most states favored a scenario in which the US continues to be the world's leading power. While China was the more preferred global leader than the US among Argentinians, the percentage difference was only $3.1 \%$ (36.5 compared to 33.4). South Africans were also almost evenly divided (44.9\% selecting the US while $39.64 \%$ chose China). Tunisia was an exception as overwhelmingly more respondents chose China (64.31\%) over the US (25.41\%).

As for the G-2 scenario, which envisions both the US and China to lead the world together, support was high among Italians (17.16\%), Israelis (13.8\%), and Hungarians (11.58\%). However, the percentage of respondents who thought the global order led by the G-2 would make the world better off were below 10 in most states in the sample. In most states, compared to the G-2 scenario, respondents preferred the G-0 scenario, which expects neither the US nor China to lead the world, with states like Israel, Kenya, and the Philippines being exceptions.

In short, generally, individuals in 24 sample states believed that the US acting as a leading power would make the world better off in the future with some exceptions. While there were respondents who said China, G-2, or G-0 should be the leading power, in most states, the percentage was lower than those who selected the US. 


\section{INDIVIDUAL-LEVEL INDEPENDENT VARIABLES AND HYPOTHESES}

As of 2018, the US still maintains its status as the global hegemon considering the size of its economy and military spending, although its gap with China has continued to narrow in recent years. Thus, I assume that respondents who hold a positive view toward the US (focusing on how the government treats its citizens and how it acts on the world stage) will continue to support a US-led global order. I therefore derive the following hypothesis:

Hypothesis 1: Individuals who have a positive perception of the US are more likely to favor a future scenario in which the US acts as the world's leading power.

To measure whether respondents perceive the US positively, I utilized four survey questions: Do you think the government of the US respects the personal freedoms of its people? (Q30), Do you think the US plays a more important and powerful role as a world leader today compared to 10 years ago, less important role, or about as important a role as a world leader as it did 10 years ago?(Q31); In your opinion, compared with a few years ago, is the US doing more to help address major global problems, doing less, or about the same? (Q38); In making international policy decisions, to what extent do you think the US takes into account the interests of countries like (survey country)? (Q39).

Responses to these questions were recoded, so positive answers such as "More important role," "Doing more," and "Great deal" would indicate a more positive perception of the US. With the four survey items, I created an index summarizing the overall degree to which respondents positively or negatively view the US, using a principal component analysis. The range of the summary index is from -2.243 to 2.241 with 0 and 1 as a mean and a standard deviation, respectively. Higher values of the index indicate that individuals have positive attitudes toward the US.

Besides attitudes toward the US, individuals' views toward China could also affect which future scenario they would support. Thus, I assume that respondents who negatively perceive China would be more likely to prefer a US-led global order. I therefore derive the following hypothesis:

Hypothesis 2: Individuals who have a negative perception of China are more likely to favor a future scenario in which the US acts as the world's leading power.

Because there were not enough various items to create a summary index, I only used one item to measure respondents' perception of China: Do you think that [China's power and influence] is a major threat, a minor threat, or not a threat to 
(survey country)?'(Q22). Responses to the question ("Not a threat," "Minor threat," and "Major threat") were recoded, so a higher value would represent a more negative attitude.

Other than whether one perceives the US and China either positively or negatively, individuals' attitude toward values such as freedom, human rights, or free trade can also affect their views on who should lead the world. Especially for those who think they live in a state where democratic values such as transparency, fairness, and freedom are respected, I expect them to prefer a global order led by the US, which proclaims the promotion of democracy as one of its main foreign policy goals (although such an action sometimes rather causes a surge of anti-American sentiments). On the other hand, China, an authoritarian state, is often criticized (especially by the Western world) for committing human rights violations, repressing its own people, including those in the Xinjiang region. In response to such human rights abuses, some voices call for US leadership to condemn and take action toward China (Natta 2020).

I will therefore test the following hypothesis:

Hypothesis 3: Individuals who think their home state respects democratic values are more likely to favor a future scenario in which the US acts as the world's leading power.

To measure individuals' attitudes toward their country's state of democracy, I used the following survey question: Elected officials care what ordinary people think (Q34a); The court system treats everyone fairly $(\mathrm{Q} 34 \mathrm{~b})$; Most politicians are corrupt (Q34c); The rights of people to express their views in public are protected (Q34f); Most people have a good chance to improve their standard of living $(\mathrm{Q} 34 \mathrm{~g})$.

Responses to these questions were recoded, so positive answers such as "Very well" and "Somewhat well" would indicate higher satisfaction with how democracy works in their states, with responses to Q34c as an exception. With these five survey items, I created an index summarizing the overall degree to which respondents have a positive or negative perception of their home state's level of democracy, using a principal component analysis. The range of the summary index is from -2.128 to 2.134 with 0 and 1 as a mean and a standard deviation, respectively.

Finally, the US and China are the two world's largest trading states. While they are the world's largest exporters (in the order of China and the US), they are also the world's number one and two importers (in the order of the US and China). In other words, other states can benefit from increasing their exports to the US and China, which are the two largest markets in the world. However, the precondition 
necessary to increase exports to the US and China would be an open and stable global economic order that allows the free flow of goods and services. The global free trade system will not operate if protectionism and trade wars prevail. Therefore, I expect individuals who support the liberal idea that free trade makes every participant better off to prefer a future world led by G-2 in which the US and China seek cooperation and harmony. Specifically, I propose the following hypothesis:

Hypothesis 4: Individuals who support global free trade are more likely to favor a future scenario in which both the US and China act as the world's leading powers than the other scenarios.

To measure individuals' attitudes toward global free trade, I utilize the following survey question: What do you think about the growing trade and business ties between (survey country) and other countries? (Q25). Responses to this question were recoded, so positive answers such as "Very good" and "Somewhat good" would indicate higher support for free trade.

Finally, I added general demographic variables such as individuals' age and gender as control variables. Among other general demographic variables, I did not include education because response categories varied considerably among states so that it was not possible to standardize and categorize them into a universal groupings such as "less than high school degree," "high school degree or equivalent," and "at least some college education." I also was not able to include respondents' socioeconomic status as a control variable because of the same reason.

\section{STATE-LEVEL CONTROL VARIABLES}

Since this study intends to examine which of the four future scenarios individuals think would be good for the world, the main independent variables of interest are concentrated at the individual-level. Still, because individuals in the sample are nested within 24 different states, which state they are in (level-2 unit) could also have an impact on individuals' views (level-1 unit). In other words, the effects of various factors operating at different levels should be disentangled to properly distinguish which variable has an impact on the dependent variable. Besides, state-level variables are added as control variables to minimize the within-group (state) effect on individuals' perception of global leadership, so the assumption of empirical models that there are no correlations among observations can be met (Rabe-Hesketh and Skrondal 2012). All the state-level control variables are lagged by a year (2017 data), assuming that they affect 
individuals' attitudes gradually rather than having an instant effect.

Various state-level factors can affect the relations between G-2 states and respondents' home states. Those factors include whether states are located in the Asia-Pacific region, freedom status (democracy), shared interests, and trade relations, among other things.

As mentioned above, compared to individuals in other regions, the percentage of respondents who prefer the US as the world's leading power were exceptionally high in the Asia-Pacific region states. Such results, shown in Table 1, suggest that states' location can affect individuals' preference for future global leaders. Therefore, I included a dummy variable assigning 1 to Asia-Pacific states (Australia, Indonesia, Japan, the Philippines, and South Korea) and 0 to others.

Meanwhile, similar to individuals' views on freedom, states' freedom status can also affect their relations with the US or China. For instance, although the validity of the empirical results is debatable, democracies do not go to war against other democracies. Instead, they maintain peaceful relations among themselves, according to the democratic peace thesis (Maoz and Russett 1993; Oneal et al. 1996). Applying this democratic peace thesis to current relations between states, I expect individuals in more advanced democracies to be more likely to favor a global order led by the US (a democratic state) than China (an authoritarian state). To measure how advanced a state's democracy is, I used the Freedom House Freedom Status Aggregate Score (which combines a state's political liberty and civil rights scores). The indicator ranges from 0 to 100, with a higher score representing a more free status. Although I have limited the state samples to democracies, their freedom status score varies from 50 (Nigeria) to 99 (Canada and Netherlands).

Another state-level factor that affects relations between states is whether they have shared interests regarding global issues - a national affinity. The UN General Assembly (UNGA) roll call votes data measures similarity in the votes cast (yes/no) by two states in a given year, ranging from -1 to 1 (Voeten et al. 2020). High similarity (a score close to 1 ) in votes cast indicates that two states share similar interests regarding global issues such as human rights, nuclear proliferation, sanctioning North Korea, climate change, aiding low-income economies, and others. Thus, I expect individuals in a state that has a similar preference (shared interest) with either the US or China are more likely to have favorable views toward that state. (Using the UNGA 2017 roll call votes data, I checked the correlation between sample states' national affinity with the US and the affinity with China. The result shows a correlation of -0.9043 , indicating that those states that share similar national preferences with the US share little interest with China. Due to the high correlation, I only included states' national affinity with 
the US in the empirical models to avoid a multicollinearity problem.)

Finally, trade relations can also shape bilateral relations. According to the commercial peace thesis, states try to avoid costly conflicts with others that can negatively affect beneficial trade relations (Oneal and Russett 1999; Russett and Oneal 2001; Hegre et al. 2010). Because the opportunity cost of disruption in trade can cause severe damage to a state's economy, state leaders have incentives to maintain positive relations, especially with its trade partners. Thus, I expect individuals' preference regarding whether they support the global order led by the US or China will be affected by which of the two their home state is economically more dependent on. A state's level of dependence on the US and China is measured by calculating the bilateral trade-to-GDP ratio of each sample state. Each state's absolute value of trade (US\$ millions) with the US and China data are taken from the IMF's Direction of Trade Statistics (DOTS) (2020). Each state's GDP data is obtained from the World Bank "GDP (current US\$)" (n.d.).

\section{EMPIRICAL ANALYSIS}

Stata 16.1 version was used for empirical analysis. Considering the categorical nature of the dependent variable, I employed multinomial logistic regression models for empirical analysis while assigning the US-led world scenario as the base category. Also, since I used both individual-and state-level independent and control variables simultaneously, as mentioned above, I employed multilevel analysis. Overall, multilevel multinomial logistic regression models are used to analyze the factors that affect individuals' preferences regarding the four scenarios on the future of global leadership. ${ }^{2}$ Additionally, individuals' probability weights are applied to take into account each individual's different probability of being sampled. Besides, standard errors are clustered by each state (24 states), generating robust standard errors of the coefficients. Answers such as "Don't know" and "Refused" are removed from the analysis. Finally, the interpretations of coefficients are based on the ceteris paribus assumption.

2 As a post-estimation test, I tried to check whether the multilevel multinomial logistic regression models have violated the Independence of Irrelevant Alternatives (IIA) assumption. However, because I applied probability weights and clustered the sample into 24 states while running multilevel multinomial logistic regression, Stata 16.1 did not allow me to conduct Hausman test of IIA assumption. Therefore, the empirical results shown in Table 2 should be interpreted with caution. 
Table 2. Multilevel Multinomial Logistic Regression Model for Individuals' Preference Regarding the Future Global Leader.

\begin{tabular}{|c|c|c|c|c|c|c|}
\hline \multirow{2}{*}{$\begin{array}{c}\text { The baseline category: } \\
\text { The US is the world's leading } \\
\text { power } \\
\text { VARIABLES }\end{array}$} & \multicolumn{2}{|c|}{$\begin{array}{l}\text { China is the world's } \\
\text { leading power }\end{array}$} & \multicolumn{2}{|c|}{ Both $(\mathrm{G}-2)$} & \multicolumn{2}{|c|}{ Neither (G-0) } \\
\hline & Coefficient & $\begin{array}{l}\text { Relative } \\
\text { risk ratio }\end{array}$ & Coefficient & $\begin{array}{l}\text { Relative } \\
\text { risk ratio }\end{array}$ & Coefficient & $\begin{array}{l}\text { Relative } \\
\text { risk ratio }\end{array}$ \\
\hline \multicolumn{7}{|l|}{ Individual-leve/ variables } \\
\hline Positive perception of the US & $\begin{array}{c}-0.456^{* * * *} \\
(0.050)\end{array}$ & [0.634] & $\begin{array}{l}-0.181 \\
(0.125)\end{array}$ & [0.834] & $\begin{array}{c}-0.738^{* * * *} \\
(0.041)\end{array}$ & {$[0.478]$} \\
\hline Negative perception of China & $\begin{array}{l}-0.297^{* * *} \\
(0.043)\end{array}$ & [0.743] & $\begin{array}{l}-0.272^{* * *} \\
(0.065)\end{array}$ & {$[0.762]$} & $\begin{array}{c}0.040 \\
(0.052)\end{array}$ & {$[1.040]$} \\
\hline $\begin{array}{l}\text { Home state respects } \\
\text { democratic values }\end{array}$ & $\begin{array}{l}-0.092^{*} \\
(0.045)\end{array}$ & [0.912] & $\begin{array}{c}0.007 \\
(0.083)\end{array}$ & {$[1.007]$} & $\begin{array}{l}-0.343^{* * *} \\
(0.076)\end{array}$ & {$[0.710]$} \\
\hline Support international Trade & $\begin{array}{l}-0.043 \\
(0.045)\end{array}$ & [0.958] & $\begin{array}{c}-0.214^{* *} \\
(0.077)\end{array}$ & {$[0.807]$} & $\begin{array}{l}-0.055 \\
(0.065)\end{array}$ & [0.947] \\
\hline Male & $\begin{array}{l}-0.043 \\
(0.062)\end{array}$ & [0.958] & $\begin{array}{l}-0.003 \\
(0.078)\end{array}$ & [0.997] & $\begin{array}{l}-0.062 \\
(0.077)\end{array}$ & [0.940] \\
\hline Age & $\begin{array}{l}-0.010^{* * *} \\
(0.002)\end{array}$ & [0.990] & $\begin{array}{l}-0.001 \\
(0.003)\end{array}$ & [0.999] & $\begin{array}{l}-0.002 \\
(0.002)\end{array}$ & [0.997] \\
\hline \multicolumn{7}{|l|}{ State-level variables } \\
\hline Asia-Pacific countries & $\begin{array}{c}-0.507^{* *} \\
(0.226)\end{array}$ & [0.602] & $\begin{array}{l}-0.375 \\
(1.127)\end{array}$ & [0.687] & $\begin{array}{l}0.014 \\
(0.523)\end{array}$ & {$[1.014]$} \\
\hline Democracy & $\begin{array}{l}-0.014 \\
(0.010)\end{array}$ & [0.986] & $\begin{array}{l}-0.045^{*} \\
(0.025)\end{array}$ & {$[0.956]$} & $\begin{array}{l}-0.021 \\
(0.015)\end{array}$ & [0.979] \\
\hline National affinity: US & $\begin{array}{c}-2.444^{* *} \\
(0.994)\end{array}$ & {$[0.087]$} & $\begin{array}{l}2.350 \\
(1.743)\end{array}$ & [10.491] & $\begin{array}{l}1.773^{* *} \\
(0.768)\end{array}$ & [5.888] \\
\hline Trade dependence on the US & $\begin{array}{l}-0.278 \\
(0.269)\end{array}$ & {$[0.757]$} & $\begin{array}{l}-4.658^{* *} \\
(1.666)\end{array}$ & [0.009] & $\begin{array}{l}-2.082^{* * *} \\
(0.718)\end{array}$ & {$[0.124]$} \\
\hline Trade dependence on China & $\begin{array}{l}-4.220 \\
(2.666)\end{array}$ & {$[0.014]$} & $\begin{array}{c}3.489 \\
(10.060)\end{array}$ & [32.753] & $\begin{array}{l}-1.335 \\
(4.406)\end{array}$ & {$[0.263]$} \\
\hline Constant & $\begin{array}{c}2.994^{* * *} \\
(0.617)\end{array}$ & [19.972] & $\begin{array}{c}1.007 \\
(1.708)\end{array}$ & {$[2.737]$} & $\begin{array}{l}-0.819 \\
(1.271)\end{array}$ & [0.441] \\
\hline Observations & \multicolumn{6}{|c|}{19,614} \\
\hline State Number & \multicolumn{6}{|c|}{24} \\
\hline
\end{tabular}

Robust standard errors in parentheses

${ }^{* * *} \mathrm{p}<0.01,{ }^{* *} \mathrm{p}<0.05,{ }^{*} \mathrm{p}<0.1$

As shown in Table 2, respondents who have an overall positive attitude toward the US were less likely to prefer China (more likely to select the US) acting as the world's leader in the future $(p<0.01)$, providing empirical evidence that supports Hypothesis 1 . These individuals were also less likely to support the G-0 order than the US-led order $(p<0.01)$. Specifically, if an individual's positive perception of 
the US increases by one unit, the relative risk for preferring China to the US is expected to decrease by a factor of 0.634 . Also, a one-unit increase in individuals' positive perception of the US is expected to reduce the relative risk for preferring the G-0 order to the US by a factor of 0.478 .

Meanwhile, those who see China's power and influence negatively were less likely to support a China-led global order (more likely to support US-led global order) $(p<0.01)$, providing empirical evidence that supports Hypothesis 2 . They were also less likely to support a G-2 order, in which China acts as one of the world's leaders $(p<0.01)$. Given a one-unit increase in the respondents' negative perception of China, the relative risk for supporting China over the US is expected to decrease by a factor of 0.743 . Also, if an individual's negative perception of China increases by one unit, the relative risk for preferring the G-2 order compared to the US is expected to decrease by a factor of 0.762 .

As for individuals' views on how democracy works in their country, those who have a positive perception were less likely to select China as a state that should lead the world in the future $(p<0.1)$, as expected by Hypothesis 3 . Those with a positive attitude were also less likely to choose a G-0 order. Specifically, a one-unit increase in one's perception of his/her home state's level of democracy is expected to decrease the relative risk of preferring China over the US by a factor of 0.912 . It is also expected to reduce the relative risk of selecting a G-0 order by a factor of 0.710 .

Regarding Hypothesis 4, those who think trade and business ties with other states are good for their home state were less likely to believe the world would be better off when it is led by the G-2 $(p<0.05)$ than when it is led by the US, with a relative risk ratio of 0.807 , contradicting what was predicted. However, support for international trade showed no association with individuals' preference for China over the US or the G-0 over the US. Thus, the empirical results suggest that there is no consistent evidence for whether support for international trade shapes individuals' preferences for the four scenarios. Particularly, attitudes toward trade did not influence individuals' preference for the US or China as the global leader.

As for the state-level variables, respondents in Asia-Pacific countries were less likely to support China as the global leader compared to the US $(p<0.05)$. For individuals in Asia-Pacific states compared to those in other regions, the relative risk for preferring China over the US is expected to decrease by a factor of 0.602 . These results suggest that individuals in China's neighboring countries are more sensitive and anxious about China's rise and the negative impact it can have on their home state compared to those in other regions.

Meanwhile, individuals in democracies were less likely to favor a G-2 world ( $p$ 
$<0.1$ ) over a US-led world, with a relative risk ratio of 0.956 . However, surprisingly, they were not particularly more likely to support a US-led global order than one led by China as there was no statistically significant association in this case. The result seems to need further investigation so we can explain the outcome because, although it does not contradict what was predicted by Hypothesis 3, it is also inconsistent with that finding. One of the possible reasons home states' higher freedom scores were not associated with respondents' preference for the US over China is because, as mentioned above, this study limited its scope to democracies due to theoretical reasons and data availability. In other words, the data is truncated, including only states that are at least "partly free" with a Freedom Status Aggregate Score above 50. Therefore, the state-level Democracyvariable might reveal its impact on respondents' attitudes toward the US and China if we could also find more balanced data that includes respondents from numerous non-democracies. In other words, we need a sample of states that can represent the population of states, not only democracies, to properly test whether individuals living in democracies would support the US, not China, as the global leader.

Besides, individuals in states with a high degree of national affinity with the US were less likely to think the world would be better if China leads it $(p<0.05)$. The result indicates that individuals in states that maintain close relations with the US were more likely to support the US-led global order. Specifically, a one-unit increase in their home state's national affinity with the US is expected to decrease individuals' relative risk for preferring China by a factor of 0.087 . On the other hand, those individuals were more likely to prefer the world led by the G-0 ( $p<$ $0.05)$, increasing the relative risk for preferring a G-0 order over the US by a factor of 5.888. While the first outcome is understandable, the second outcome needs further investigation to understand why individuals in states that share interests with the US still support a G-0 global order. One possible answer to this questionable result is the small sample size of those who selected "Neither (G-0)" as the best future scenario. As shown in Table 1, only $10.51 \%$ of the total respondents selected this category, possibly producing an unexpected but statistically significant result. Therefore, the empirical results associated with "Both (G-2)" and "Neither (G-0)" categories should be interpreted with caution.

Finally, individuals favored a US-led global order over one led by the G-2 or the G-0 as their states' trade dependence on the US increased $(p<0.05$ and $p<0.01$, respectively). Specifically, the relative risk ratio for choosing the G-2 over the US was 0.009 , while the ratio for choosing the G-0 over the US was 0.124 , respectively, as their home state's trade dependence on the US increased one unit. However, increased dependence on the US did not affect individuals 'preference for the US 
over China. Such outcomes are similar to what we found when testing Hypothesis 4 - at the individual level, support for international trade and business showed no association with preferring either the US or China as the future global leader. Regarding their home states' increased trade dependence on China, it also did not affect individuals 'preference for China over the US as the future global leader. It also showed no association with respondents' support a G-2 or G-0 scenario over a China-led global order. Overall, either attitude toward trade (individual-level) or their home state's trade relations (state-level) had no impact on individuals' choice between the US or China. In other words, the empirical results shown in Table 2 suggest that whether respondents prefer the US or China as the global leader might depend more on non-economic factors discussed in Hypotheses 1 through 3.

In Figures 1 through 5, I present the predicted probabilities of choosing one of the four future scenarios based on how respondents answered each of the individual-level independent variables used to test the hypotheses.

Figure 1. Predicted probabilities of choosing a future global leader: The perception of the US (higher values indicate more positive attitudes)

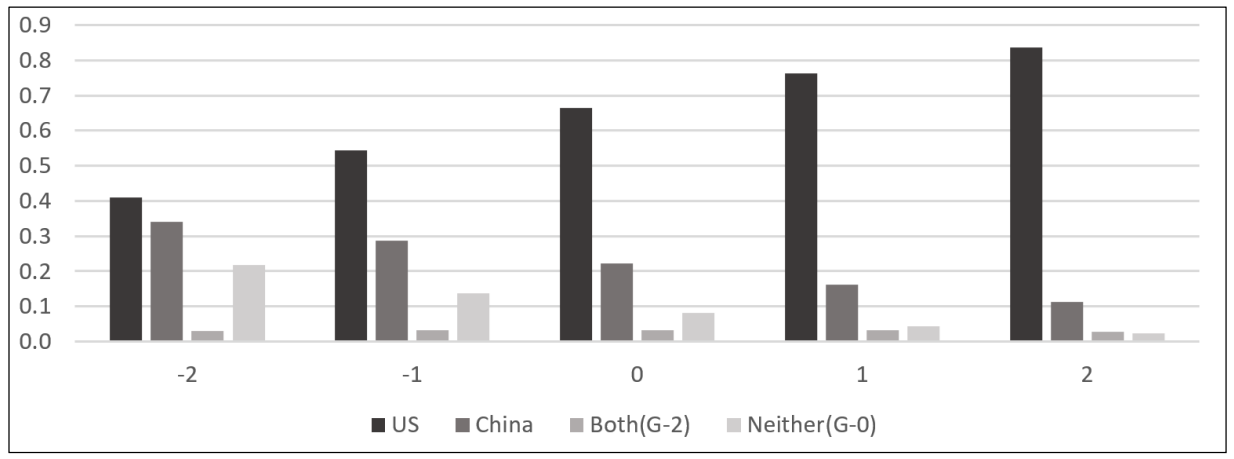


Figure 2. Predicted probabilities of choosing a future global leader :

Do you think China's power and influence is a threat to (survey country)?

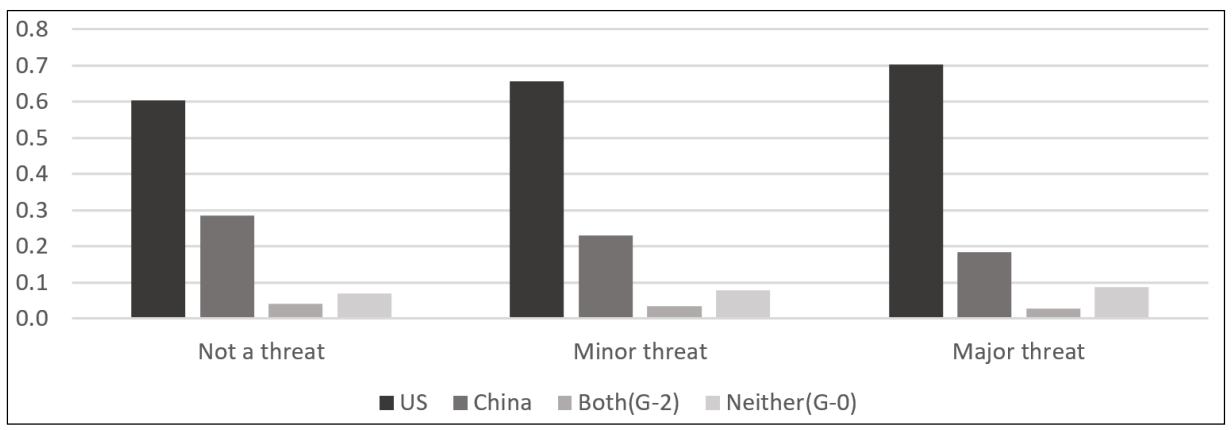

Figure 3. Predicted probabilities of choosing a future global leader: perception of home state's democracy (higher values indicate more positive attitudes)

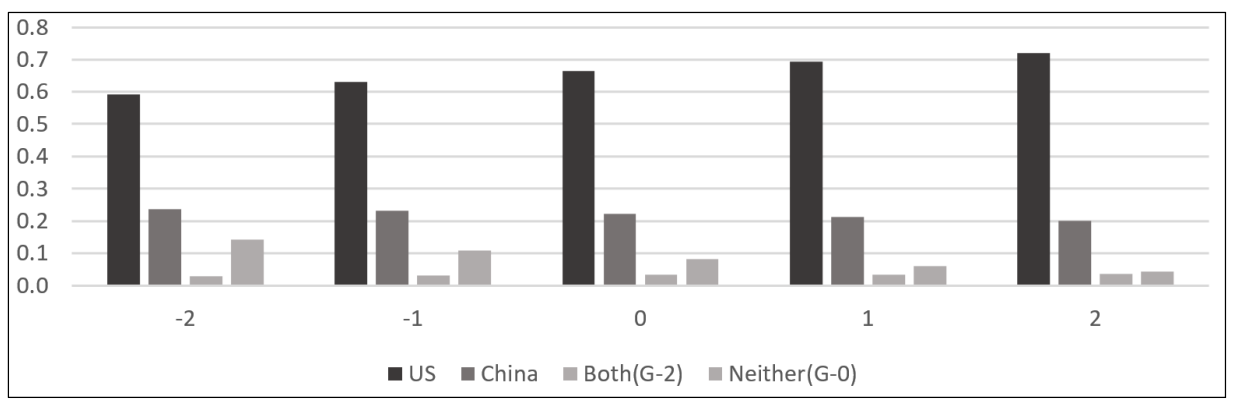

Figure 4. Predicted probabilities of choosing a future global leader: Is global free trade good for your state?

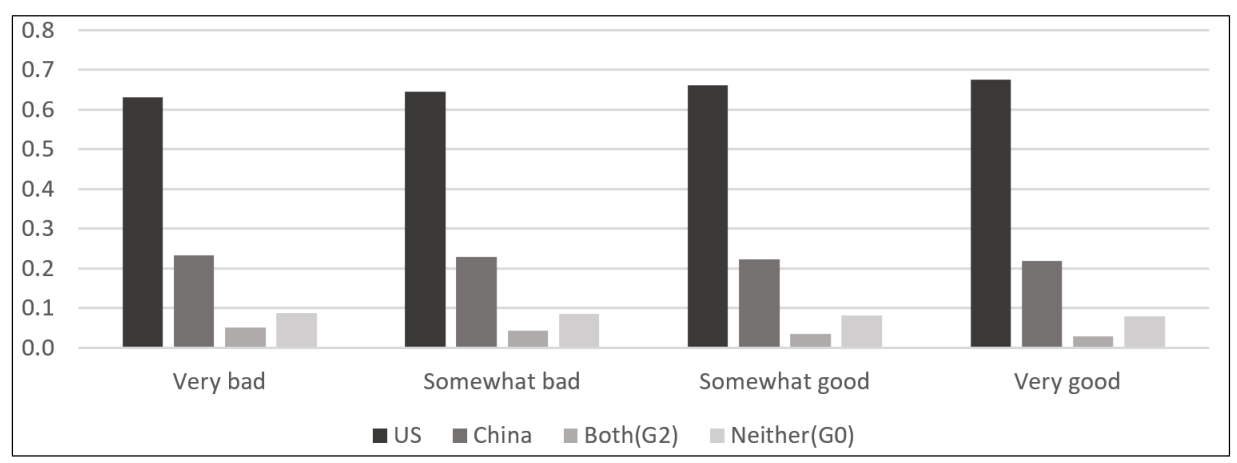


As shown in Figure 1, as individuals had more positive perceptions of the US (as the summary index increased from -2 to 2), the predicted probabilities of believing that US leadership would be better for the future increased from 0.4105 to 0.8354 . In Figure 2, the predicted probabilities of choosing the US as the preferable future leader increased from 0.6039 to 0.7014 as the degree to which respondents believed that China's power and influence is a threat to their home state increased (from "no a threat" to "major threat"). Similarly, Figure 3 shows that the predicted probabilities of choosing the US over other options increased from 0.5908 to 0.7194 as respondents had more positive perceptions of whether their home states respect democratic values (from "-2" to "2"). Overall, the results shown in Figures 1 through 3 support Hypotheses 1 through 3 that individuals with a positive perception of the US, a negative perception of China, and a positive view toward their home state's level of democracy are more likely to prefer a global order led by the US over other scenarios.

Besides, the predicted probabilities of choosing the US as the preferable future leader increased from 0.6305 to 0.6746 as respondents have a more positive attitude toward free trade (from "very bad" to "very good"). Hypothesis 4 predicted that those who have a positive attitude toward global free trade would be more likely to support a global order led by the G-2 (which are two of the world's largest trading states). However, the empirical results showed that individuals do not particularly prefer the US or China as the global leader when it comes to increasing trade and business ties between states. The predicted probabilities of preferring G-2 leadership over others also gradually decreased from 0.0510 to 0.0287 as individuals had a more positive perception of global trade, as shown in Figure 4. Therefore, there is not enough empirical evidence that supports Hypothesis 4.

\section{CONCLUSION}

In this article, I examined global public opinion regarding which of the four possible scenarios individuals support - a world led by 1) the US, 2) China, 3) both, or 4) neither. I also attempted to investigate the factors shaping individuals' choices for future scenarios. To answer my research question, I analyzed the 2018 PRC survey data by employing multilevel multinomial logistic regression models.

The empirical results of the analysis showed that individuals who perceived the US positively were less likely to think the world would be better off if China led the world. Also, US. Individuals were also less likely to prefer an order led by 
China as they viewed China's influence and power negatively. Besides, individuals were less likely to select a China-led global order if they held more positive views regarding whether their home state was democratic. In other words, individuals who think they live in a democratic state want to continue to see the US, rather than China, acting as the global leader. Finally, individuals' attitudes toward trade produced results that were less clear to interpret. Respondents who have a positive attitude toward global trade were more likely to support an order led by the US over the G-2 or the G-0. Those individuals, however, did not particularly choose the US as a preferable global leader over China. Because China is one of the two largest trading states in the world, it seems the global public who thinks free trade benefits their state cannot make a clear decision on which scenario would be good for the world when it comes to choosing between the US or China.

As pointed out earlier, public opinion can have a significant impact when governments make foreign policy decisions. Thus, which scenario the public favors can be one of the determinants of how states, especially democracies, will react toward US or China's leadership in the future. So far, most of the existing literature focused on identifying state-level factors that can influence whether the US or China will be the world leader in the future and how other states will respond in that situation. In this sense, this article makes contributions by examining the factors affecting individuals' attitudes regarding the future of global leadership, filling the gap that exists in previous studies.

As mentioned above, however, there were signs that the US intended to abandon its role as a global hegemon. Especially under the Trump administration, the US withdrew itself from several international treaties and institutions. Thus, although the global public in the sampled states showed intentions to continue and support the US as the global leader, it is unclear whether the US has the will to continue to assume its role that others want it to serve.

One of the limitations of this study is that I had to narrow down the sample's scope to only democracies due to the nature of the survey data I used. Because the 2018 PRC survey was conducted mostly in democracies, generalizing the empirical results would produce misleading findings that democracies represent the population of states. Therefore, surveys that have also been conducted in non-democracies are necessary to obtain results that genuinely represent the global population's opinions regarding future global leadership.

Finally, although I attempted to investigate which of the four scenarios individuals think is good for the world, I was not able to clearly define whether the world led by China indicates a world in which the status quo persists or a completely different world that reflects China's interests. The survey question 
used as the dependent variable of the empirical models does not clarify what exactly a world led by China entails. Thus, we cannot know whether respondents selected this scenario while regarding China as a state pursuing the status quo or having revisionist intentions to reshape the global order so it will serve its interest. In other words, the empirical findings shown in this study need to be interpreted with caution.

\section{ACKNOWLEDGEMENT}

The author wants to thank the three anonymous reviewers for providing helpful and constructive comments.

\section{REFERENCES}

Ahmad, Khurshid. 2011. "US Policies, Ensuing Terrorism and Anti-Americanism: Some Reflections." Policy Perspectives 8(1), 37-47.

Armony, Ariel C., and Nicolás Velásquez. 2015. "Anti-Chinese Sentiment in Latin America: An Analysis of Online Discourse." Journal of Chinese Political Science 20(3), 319-346.

Beeson, Mark, and Nathan Watson. 2019. "Is International Leadership Changing Hands or Disappearing? China and the USA in Comparative Perspective." Asian Perspective 43(2), 389-417.

Berendse, Gerrit-Jan. 2003. "German Anti-Americanism in Context." Journal of European Studies 33(3/4), 333-350.

Carlson, Matthew, and Travis Nelson. 2008. "Anti-Americanism in Asia? Factors shaping international perceptions of American influence." International Relations of the Asia-Pacific 8(3), 303-324.

Chellaney, Brahma. 2019. "The Global War on Terrorism Has Failed. Here's How to Win.” Foreign Policy (May 11). Accessed at https://foreignpolicy. com/2019/05/11/the-global-war-on-terrorism-has-failed-heres-how-towin/ (September 14, 2020).

Chiozza, Giacomo. 2009. "A Crisis Like No Other?: Anti-Americanism at the Time of the Iraq War." European Journal of International Relations 15(2), 257-289.

Christensen, Thomas J. 1999. "China, the U.S.Japan Alliance, and the Security Dilemma in East Asia." International Security 23(4), 49-80.

Christensen, Thomas J. 2001. "Posing Problems without Catching Up: China's 
Rise and Challenges for US Security Policy." International Security25(4), $5-40$.

Chung, Alec. 2015. "Effects of Trade Relations on South Korean Views of China." Asian Politics \& Policy 7(4), 597-621.

Direction of Trade Statistics (DOTS). 2020. International Monetary Fund. Accessed at https://data.imf.org/?sk=9D6028D4F14A-464C-A2F2-59B2CD424B 85\&sId=1514498277103 (September 19, 2020).

Fordham, Benjamin O. 1998. "Partisanship, Macroeconomic Policy, and US Uses of Force, 1949-1994." Journal of Conflict Resolution 42(4), 418-439.

Freedom House. 2017. "Freedom in the World 2017." Accessed at https:// freedomhouse.org/sites/default/files/FH_FIW_2017_Report_Final.pdf ( September 19, 2020).

Gelpi, Christopher, and Joseph M. Grieco. 2003. "Economic Interdependence, the Democratic State, and the Liberal Peace." In Edward D. Mansfield and Brian M. Pollins eds., Economic Interdependence and International Conflict: New Perspectives on an Enduring Debate. Ann Arbor: University of Michigan Press, 44-59.

Gilpin, Robert. 2008. War and Change in World Politics. Cambridge, UK: Cambridge University Press.

Halper, Stefan. 2010. The Beijing Consensus: How China's Authoritarian Model Will Dominate the Twenty-First Century. Basic Books.

Hegre, Håvard, John R. Oneal, and Bruce Russett. 2010. "Trade does promote peace: New simultaneous estimates of the reciprocal effects of trade and conflict." Journal of Peace Research 47(6), 763-774.

Ikenberry. G. John. 2003. "Is American Multilateralism in Decline?" Perspective on Politics 1(3), 533-550.

Jhee, Byong-Kuen. 2008. "Anti-Americanism and Electoral Politics in Korea." Political Science Quarterly 123(2), 301-318.

Kent, Ann. 2013. China, the United Nations, and Human Rights: The Limits of Compliance. Philadelphia: University of Pennsylvania Press.

Keohane, Robert O. 2005. After Hegemony: Cooperation and Discord in the World Political Economy. Princeton, NJ: Princeton University Press; Revised Edition.

Kindleberger, Charles. 2013. The World in Depression, 1929-1939. Berkeley, CA: University of California Press; First Edition, 40th Anniversary.

Krauthammer, Charles. 1995 "Why We Must Contain China," Time (July 31). Accessed at http://content.time.com/time/magazine/article/0,9171,983245, 00.html (September 10, 2020).

Krepinevich Jr., Andrew F. 2015. "How to deter China: the case for archipelagic 
defense." Foreign Affairs, 94(2), 78-86.

Lee, Dong Sun. 2007. "Democratization and the US-South Korean Alliance." Journal of East Asian Studies 7(3), 469-499.

Liang, Wei. 2007. "China: Globalization and the Emergence of a New Status Quo Power?" Asian Perspective 31(4), 125-149.

Maoz, Zeev, and Bruce Russett. 1993. "Normative and Structural Causes of Democratic Peace, 1946-1986.” The American Political Science Review 87(3), 624-638.

McLean, Elana V. and Taehee Whang. 2014. "Designing Foreign Policy: Voters, Special Interest Groups, and Economic Sanctions.” Journal of Peace Research 51(5), 589-602.

Mearsheimer, John J. 1990. "Back to the Future: Instability in Europe after the Cold War." International Security 15(1), 5-56.

Mearsheimer, John J. 2010. "The Gathering Storm: China's Challenge to US Power in Asia." The Chinese Journal of International Politics 3(4), 381-396.

Mearsheimer, John J. 2014. The Tragedy of Great Power Politics. New York, NY: W. W. Norton \& Company; Updated Edition.

Moravcsik, Andrew. 1997. "Taking preferences seriously: a liberal theory of international politics." International Organization 51(4), 513-553.

Morgan, Pippa. 2019. "Can China's Economic Statecraft Win Soft Power in Africa? Unpacking Trade, Investment and Aid.” Journal of Chinese Political Science 24(3), 387-409.

Natta, Pierfilippo M. 2020. "China's Human Rights Abuses Invite US Leadership." The Diplomat (August 8). Accessed at https:/thediplomat.com/2020/08/ chinas-human-rights-abuses-invite-us-leadership/ (September 19, 2020).

Nye Jr, Joseph S. 2016. Bound to Lead: The Changing Nature of American Power. New York: Basic Books.

Oneal, John R., Frances H. Oneal, Zeev Maoz, and Bruce Russett. 1996. "The Liberal Peace: Interdependence, Democracy, and International Conflict, 1950-85." Journal of Peace Research 33(1), 11-28.

Oneal, John R., and Bruce Russett. 1999. "The Kantian Peace: The Pacific Benefits of Democracy, Interdependence, and International Organizations, 1885-1992." World Politics 52 (1), 1-37.

Pan, Hsin-Hsin. 2020. "Is the USA the Only Role Model in Town? Empirical Evidence from the Asian Barometer Survey." Journal of Asian and African Studies 55(5), 733-749.

Page, Benjamin I. and Robert Y. Shapiro. 1983. "Effects of Public Opinion on Policy." American Political Science Review 77(1), 175-190.

Papayoanou, Paul A. 1996. "Interdependence, Institutions, and the Balance of 
Power: Britain, Germany, and World War I." International Security20(4), 42-76.

Plate, Tom. 2013. Conversations with Lee Kuan Yew: Citizen Singapore: How to Build a Nation (Conversations with Giants of Asia). Marshall Cavendish International (Asia) Pte Ltd.

Rabe-Hesketh, Sophia, and Anders Skrondal. 2012. Multilevel and Longitudinal Modeling Using Stata: Volume I. College Station, TX: STATA Press.

Roy, Denny. 1994. "Hegemon on the Horizon? China's Threat to East Asian Security." International Security 19(1), 149-168.

Roy, Denny. 1996. “The "China Threat” Issue: Major Arguments.” Asian Survey 36(8), 758-771.

Roy, Denny. 2005. "Southeast Asia and China: Balancing or Bandwagoning?" Contemporary Southeast Asia 27(2), 305-322.

Rubin, Barry. and Judith Colp Rubin. 2004. "Anti-Americanism Re-Examined." The Brown Journal of World Affairs 11(1), 17-24.

Russett, Bruce M., and John R. Oneal. 2001. Triangulating Peace: Democracy, Interdependence, and International Organizations. New York: Norton.

Simmons, Beth. 2003. "Pax Mercatoria and the Theory of the State." In Edward D. Mansfield and Brian M Pollins eds., Economic Interdependence and International Conflict: New Perspectives on an Enduring Debate. Ann Arbor: University of Michigan Press, 31-43.

Sobel, Richard. 2001. The Impact of Public Opinion on US Foreign Policy since Vietnam. Oxford: Oxford University Press.

Voeten, Erik, Anton Strezhnev, and Michael Bailey. 2020. "United Nations General Assembly Voting Data.” Harvard Dataverse. Accessed at https:// dataverse.harvard.edu/dataset.xhtml? persistentId=doi:10.7910/DVN/LE JUQZ(September 18, 2020).

World Bank. n.d. "GDP (current US\$).” Accessed at http://data.worldbank. org/indicator/NY.GDP.MKTP.CD (accessed 14 January 2020).

Wu, Wendy. 2020. "Xi Jinping uses annual conference of infrastructure bank to spell out China's multilateral and global ambitions." South China Morning Post(July 28). Accessed at https://www.scmp.com/news/china/ diplomacy/article/3095048/xi-uses-annual-conference-infrastructure-b ank-spell-out-chinas (September 15, 2020).

Yeo, Andrew. 2011. Activists, Alliances, and Anti-U.S. Base Protests. New York: Cambridge University Press..

[Received Sep 29, 2020; Revised Nov 23, 2020; Accepted Nov 24, 2020] 